\title{
RECORD OF Oreochromis aureus (STEINDACHNER, 1864) (TELEOSTEI: PERCIFORMES: CICHLIDAE) IN THE NATURAL WATERS OF TAMIL NADU, INDIA
}

\section{J. D. Marcus Knight ${ }^{1,3}$ and K. Rema Devi ${ }^{2}$}

\begin{abstract}
${ }^{1}$ Flat 'L', Sri Balaji Apartments, $7^{\text {th }}$ Main Road, Dhandeeswaram, Velachery, Chennai- 600 042, India
${ }^{2}$ Zoological Survey of India, Marine Biology Regional Centre, 130, Santhome High Road, Chennai- 600028 , India
\end{abstract}

Coresponding author: ${ }^{3}$ jdmarcusknight@yahoo.co.in

Of the many fish introduced globally for aquaculture, Tilapia can be considered as the most widely introduced species. The Mozambique Tilapia, Oreochromis mossambicus Peters, 1852, was the first species to be widely introduced for aquaculture. FAO Database on Introductions of Aquatic Species (DIAS; FAO, 2000-2009) states that $O$. mossambicus was first introduced to India during the year 1952 (Devadas \& Chako, 1953) from Sri Lanka and Thailand for aquaculture with the idea of reservoir fisheries. $O$. niloticus Linnaeus, 1758, was introduced to India as late as 1990 from Thailand. O. mossambicus has found its way into the list of 100 of the World's worst Invasive Alien Species published by Invasive Species Specialist Group (ISSG) (Lowe et al., 2000). It has established itself in the wild which may be attributed to intentional release or escapes from fish farms.

$O$. mossambicus and $O$. niloticus have become widely spread throughout Asia and occur in natural and quasi-natural waters. This has caused increased concern among conservationists and environmentalists (Pethiyagoda, 1994). A similar species, Oreochromis aureus (Steindachner, 1864), commonly called the Blue Tilapia which is a native of Africa and Middle East has also been introduced for commercial fisheries. Though there is no official record of blue tilapia being introduced into India, specimens of $O$. aureus (fig. 2A, B \& C) were collected by the senior author from water bodies in and around Pallikaranai marsh in Chennai, Tamil $\mathrm{Nadu}$, India. These fishes could have been brought in accidentally along with $O$. mossambicus fingerlings for aquaculture. The meristic details of ten specimens of $O$. aureus collected from Chennai are as follows: D.17/12-13; P.1/12-13; V.1/5; A.3/9-11; C.16; Lateral row of scales: 30-33; L.1. pored scales in upper and lower rows: 20-23/14-18 and gill rakers in the first arch: 21-23/5-7. The 
above characters agree with those given for $O$. aureus in Trewevas (1983). The lower pharyngeal bones of $O$. mossambicus and $O$. aureus of length $18.7 \mathrm{~cm} \mathrm{SL}$ and $18.1 \mathrm{~cm}$ SL respectively are shown in (Fig. 1A, B, C \& D). The blade length of the pharyngeal bone is longer than the median length of the toothed area in the former vs. the blade shorter than the median length of toothed area in the latter. The shape of the pharyngeal bone is as given for the species of $O$. aureus and for $O$. mossambicus by Trewavas (1983).

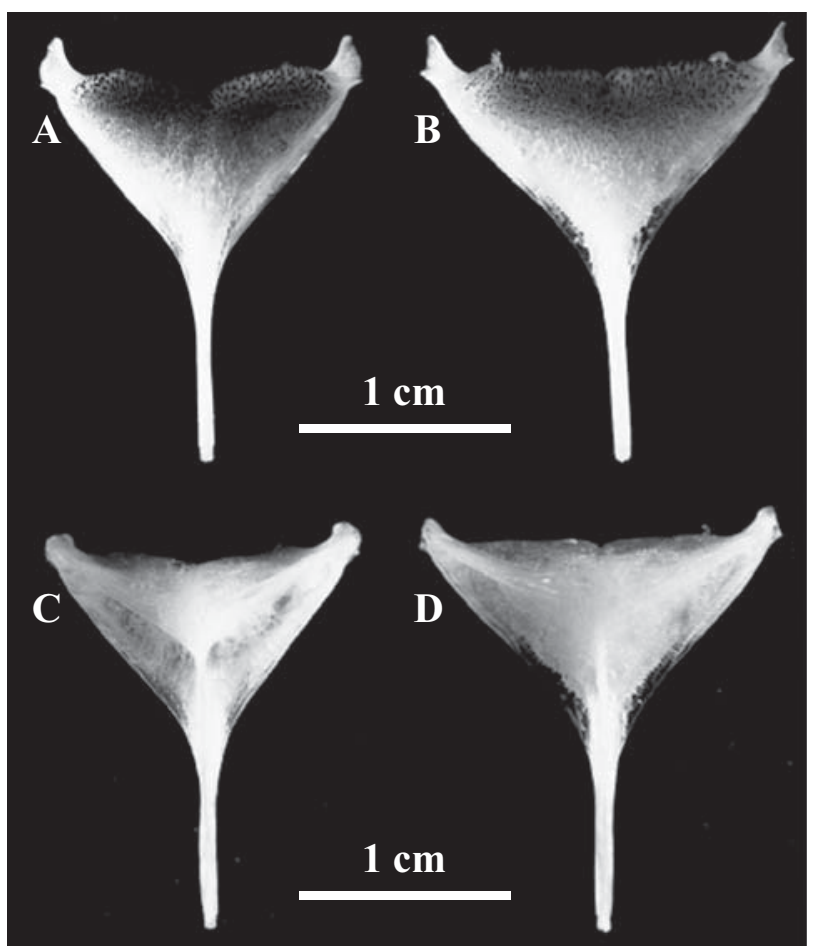

Fig. 01: The lower pharyngeal bones; A: dorsal view of O. mossambicus, B: dorsal view of $O$. aureus, C: ventral view of $O$. mossambicus, D: ventral view of $O$. aureus

The colouration of the fish can be described as grayish or bluish with a pale underside. Faint irregular bands can be seen on the sides and on the caudal fin. The distinguishing feature of O.aureus from O. mossambicus is the bands on the sides and the caudal fin. The faint bands on the tail and the broad pink distal portion also distinguishes it from $O$. niloticus which has numerous thin dark and clear bands on the caudal fin and the absence of the distal pink colouration, which character is used as the key feature for identification (Carpenter \& Niem, 2001; Trewevas, 1983). Blue tilapias are fast growers and reach $35 \mathrm{~cm}$ in the first year (Winfree \& Stickney, 1981). The females mature in a few weeks (Noble, 1989) or by the time they are $10 \mathrm{~cm}$ in length (Trewevas, 1983). Blue tilapias are freshwater fish but there are reports of them being recorded in saline waters (Shafland \& Pestrak, 1982; Trewavas, 1983). A breeding population of blue tilapia has been reported in the marine waters of Tampa Bay, Florida (Courtenay et al., 1984). The blue tilapia has a wide range of feeding habits. They are considered to be herbivores (Noble, 1989) and others consider them as zooplanktivorous taking plant matter secondarily (Sparatu \& Zorn, 1978).

The impact of blue tilapia on the aquatic ecosystem has been documented. Uprooting and deleafing of macrophytes has been recorded (Schwartz et al., 1986). Blue tilapias have also been known to reduce light penetration by nest building which causes turbidity (Noble et al., 1976) and compete for food and space with native species (Noble \& Germany, 1986). A decline in native fishes has been recorded with the invasion of $O$. aureus (Scoppettone et. al., 2005). In the water bodies in and around the Pallikaranai marsh, blue tilapias co-exist with the Mozambique tilapia and specimens have been collected with striking characteristics of the Mozambique tilapia. Three kinds of specimens have been collected. The first was the typical $O$. mossambicus, which does not have any bands in its body and the truncate caudal fin without any vertical bands is black with pink colouration restricted to the tip (fig. 2D). The gill raker count for these specimens was 15-17 on the lower arm of the first gill arch. The second type was the typical $O$. aureus with faint bands on the caudal fin with a broad pink distal region, which is the main character of this species. The gill raker count for these specimens was 21-23 on the lower arm of the first gill arch. The third type of specimen were with unclear broken bands on the caudal fin and the distal portion of the caudal fin is black with pink colouration only at the tips and also the head profile resembles that of the Mozambique tilapia (fig. 2E). These specimens had 20-22 gill rakers on the lower arm of the first gill arch which is higher than that of the Mozambique tilapia which has less than 20 gill rakers (Trewavas, 1983). The occurrence of the forms intermediate between $O$. aureus and $O$. mossambicus could be due to the natural hybridization and the cases of such hybridization have been reported from Texas (Howells, 1991). Experiments have been conducted by crossing Tilapia zilli and Tilapia guineensis and the caudal fin of hybrids resembled both the parents (Nobah et al., 2006). Therefore the specimens with caudal fin which resembled both O. mossambicus and $O$. aureus could be viewed as a hybrid giving scope to further study. 

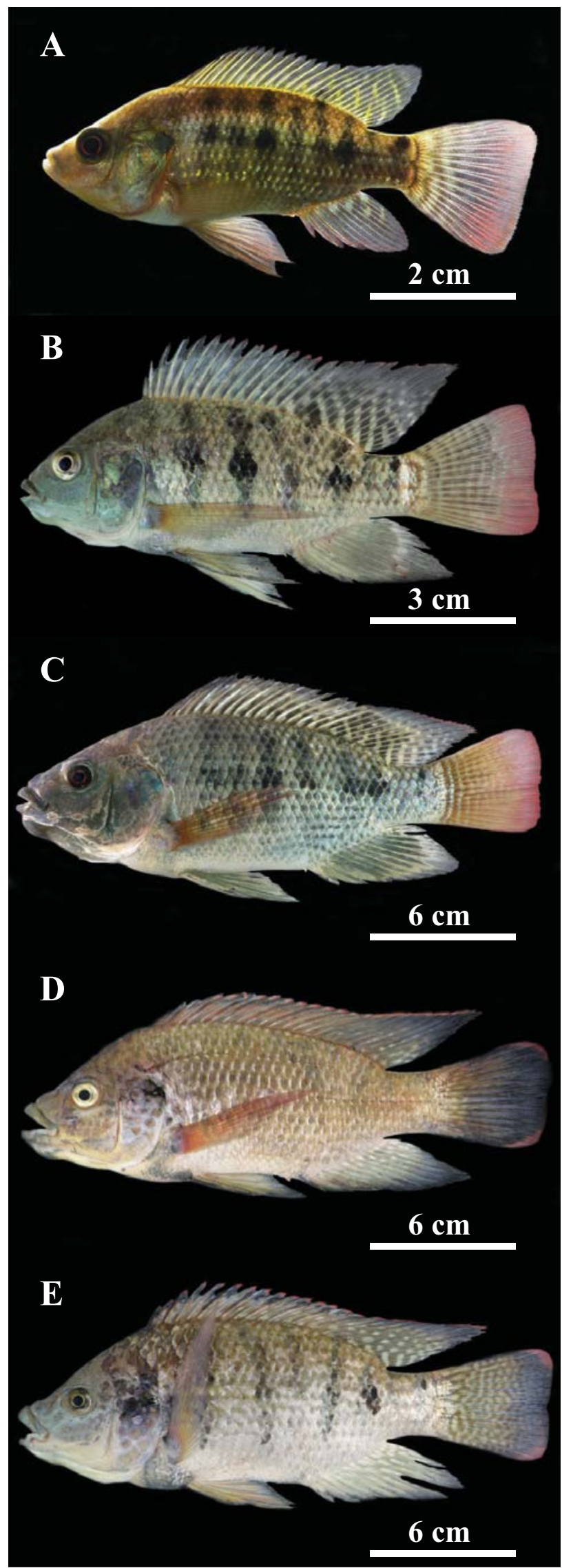

Fig. 02: (A)Juvenile $O$. aureus with pink distal end on the caudal fin, (B) Young $O$. aureus with metallic blue face, (C) Adult male O. aureus with bluish body and bright pink distal end on the caudal fin, (D) Typical $O$. mossambicus, (E) Suspected $O$. aureus $\mathrm{X} O$. mossambicus

\section{Acknowledgements}

We thank Venkat (Dolphin Aquarium-Chennai) for his help in the collection of the specimens. We express our gratitude to R. J. Ranjit Daniels, P.S. Easa and Jayantha Wijeyaratne for their constructive comments on this manuscript. We also extend our sincere thanks to Ramakrishna (Director, Zoological Survey of India) for providing infrastructure facilities.

\section{Literature Cited}

Carpenter, K. E. and V. H. Niem, 2001. FAO Species Identification Guide for Fishery Purposes. Food and Agriculture Organization of the United Nations. Rome, 5 (3): 3333 - 3336.

Courtenay, W. R. Jr., D. A. Hensley, J. N. Taylor and J. A. McCann, 1984. Distribution of exotic fishes in the continental United States. $41-77$. In: Courtenay W. R., Jr. and J. R. Stauffer Jr. (Eds.). Distribution, Biology and Management of Exotic Fishes. Johns Hopkins University Press, Baltimore.

Devadas, D. D. P. and Chacko, P. I., 1953. Introduction of the exotic cichlid fish, Tilapia mossambica (Peters) in Madras. Current Science, 22 (January): 29.

FAO, 2000-2009. The Database on Introductions of Aquatic Species (DIAS) of Food and Agriculture Organization of the United Nations (http://www.fao.org/fishery/dias/en)

Howells, R. G., 1991. Electrophoretic identification of feral and domestic tilapia in Texas. Texas Parks and Wildlife Department, Management Data Series, 62: 1 -11 .

Lowe, S., M. Browne, S. Boudjelas and M. De Pooter, 2000. 100 of the World's worst invasive alien specie: A selection from the global invasive species database. The Invasive Species Specialist Group of the Species Survival Commission (SSC) of the World Conservation Union (IUCN). 12 pp.

Nobah, C. S. K., E. P. Kouamelan, V. N'Douba, J. Snoeks, G. G. Teugels, G. Goore-Bi, Kone and T. M. Falk, 2006. The colour pattern of the caudal fin, a useful criterion for identification of two species of Tilapia and their hybrids. Journal of Fish Biology, 69 (3): $698-707$ 
Noble, R. L., 1989. Biological control for aquatic weeds using fish. Proceedings of workshop on management of aquatic weeds and mosquitoes in impoundments. Water Resources Research Institute, Charlotte, North Carolina, 247: 83 - 87.

Noble, R. L. and R. D. Germany, 1986. Changes in fish populations of Trinidad Lake, Texas, in response to abundance of blue tilapia. 455 - 461. In: Stroud, R. H. (Ed.). Fish Culture in Fisheries Management. American Fisheries Society, Maryland.

Noble, R. L., R. D. Germany and C. R. Hall, 1976. Interactions of blue tilapia and largemouth bass in a power plant cooling reservoir. Proceedings of the Annual Conference Southeastern Association of Game and Fish Commissioners, 29: 247 - 251.

Pethiyagoda, R., 1994. Threats to indigenous freshwater fishes of Sri Lanka and remarks on their conservation. Hydrobiologia, 285 (1-3): 189 -201.

Schwartz, D. P., O. E. Maughan and G. E. Gebhart, 1986. Effectiveness of blue tilapia as a weed control agent in ponds. The Progressive Fish-Culturist, 48 (4): $259-263$.

Scoppettone, G. G., J. A. Salgado and M. B. Nielsen, 2005. Blue tilapia (Oreochromis aureus) predation on fishes in the Muddy River system, Clark County, Nevada. Western North American Naturalist, 65 (3): $410-414$.

Shafland, P. L. and J. M. Pestrak, 1982. Lower lethal temperatures for fourteen non-native fishes in Florida. Environmental Biology of Fishes, 7 (2): 149 - 156.

Sparatu, P. and M. Zorn, 1978. Food and feeding habits of Tilapia aurea (Steindachner) (Cichlidae) in Lake Kinneret (Israel). Aquaculture, 13 (1): 67 - 79.

Trewevas, E., 1983. Tilapiine Fishes of the Genera Sarotherodon, Oreochromis and Danakilia. British Museum of Natural History, 878. Comstock Publishing Associates, New York: 583.

Winfree, R. A. and R. B. Stickney, 1981. Effects of dietary protein and energy on growth, feed conversion efficiency and body composition of Tilapia aurea. Journal of Nutrition, 111 (6): 1001 - 1012. 